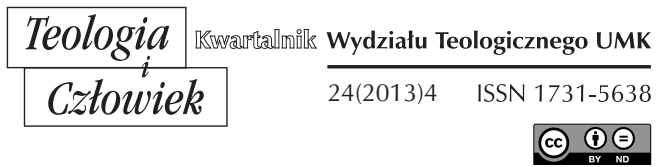

JAN PERSZON*

TORUŃ

\title{
„TO JEST JEGO KOŚCIÓŁ". BOSKI WYMIAR KOŚCIOŁA W EKLEZJOLOGII JÓZEFA RATZINGERA
}

DOI: http://dx.doi.org/10.12775/TiCz.2013.050

Kościół - przez środowiska zewnętrzne (media, prawo, nauki społeczne) traktowany zazwyczaj jako specyficzna organizacja wyznaniowa i podmiot społeczny - zapewne nigdy nie miał "dobrej prasy”. Mam na myśli zarówno krytykę, z jaką jego poszczególni przedstawiciele (i instytucje) spotykali się od początku, jak i fakt długiej tradycji zapoznawania (czyli nie-respektowania) jego nadprzyrodzonej genezy i natury. O ile jednak przez wieki mieliśmy do czynienia z - nieraz bardzo ostrą - polemiką dotyczącą nadużyć i grzechów ludzi Kościoła, która prowadziła aż do tworzenia ruchów czynnego sprzeciwu (np. herezja katarów czy waldensów), o tyle z metodyczną, bezpardonową jego krytyką zmagamy się od wybuchu reformacji luterańskiej. Doktryna Reformatorów w sposób radykalny zakwestionowała katolicką naukę o Kościele, w tym przede wszystkim jego charakter boski, nadprzyrodzony. Przyjęta przez nich koncepcja Kościoła jako Gemeinde - tworzonej przez idących za wezwaniem Chrystusa ludzi wspólnotę - odrzucała boskie pochodzenie

* Ks. prof. dr hab. Jan Perszon - kierownik Zakładu Teologii Fundamentalnej i Religiologii na Wydziale Teologicznym UMK w Toruniu. 
i zasadniczą strukturę, jaką wedle nieprzerwanej tradycji miał dać swemu Kościołowi Zbawiciel. Specyficzne rozumienie zasady solus Christus i sola Scriptura bardzo szybko uczyniły z chrześcijańskich wspólnot reformowanych Kościoły narodowe. $\mathrm{W}$ praktyce było to równoznaczne z całkowitym ich uzależnieniem od władzy świeckiej. Co więcej, wiele $\mathrm{z}$ nich zagubiło istotne wymiary właściwe prawdziwemu Kościołowi Chrystusa. Próby podobnego do protestantyzmu ułożenia relacji państwa do Kościoła (nie odrzucając jednak boskiej genezy Eklezji) podejmowali także władcy katoliccy, w czym - przynajmniej okresowo - wspierali ich teolodzy i niektórzy biskupi (gallikanizm, febronianizm, józefinizm).

Jak wiadomo, znacznie później, bo po Soborze Watykańskim II, pokusa budowania „oddolnego" Kościoła o charakterze congregatio fidelium nie ominęła także katolicyzmu nam współczesnego. Te dogasające (choć nie do końca) tendencje do protestantyzacji Kościoła widać nie tylko w osławionej teologii wyzwolenia, lecz także - szczególnie w „starej" Europie i Ameryce Północnej - w postulatach demokratyzacji struktur eklezjalnych (kierowania, zarządzania) i licznych przypadkach otwartego nieposłuszeństwa Magisterium Ecclesiae ${ }^{1}$. Kryzys w Kościele wywołał jednak nie tyle sam sobór, ile jego pospieszna i jednostronna, wygenerowana przez klimat kulturowy, recepcja². Trzeba wszakże zauważyć, że dynamiczne zmiany społeczne, w jakich uczestniczy przede wszystkim Zachód, nieuchronnie wpływają nie tylko na postrzeganie

${ }^{1} \mathrm{Z}$ istniejącym i aktywnym (zwłaszcza w krajach języka niemieckiego) ruchem „Wir sind die Kirche” J. Ratzinger polemizuje w wielu swych publikacjach. Z pokusą reformowania Kościoła wedle aktualnych upodobań polemizuje zwłaszcza w rozdziale V (Eine Gemeinschaft in steter Erneuerung). Zob. Zur Gemeinschaft gerufen. Kirche heute verstehen, Freiburg 1991, s. 124n. Warto przywołać słowa tego samego autora, który - wskazawszy na eklezjotwórcze działanie Chrystusa (Ostatnia Wieczerza) i dopełniające Ducha Świętego (Pięćdziesiątnica) - stwierdza: „W konsekwencji relacja między Kościołeminstytucją i Duchem jest zupełnie inna niż chcą nam wmówić wzmiankowane prądy. Instytucja nie jest konstrukcją, którą by można dowolnie przebudowywać i rozkładać i która nie miałaby nic wspólnego z wiarą. Tego rodzaju cielesność należy do samej istoty Kościoła. Kościół nie jest nieuchwytnym tworem, ukrywającym się pod mnogością ludzkich pomysłów; on istnieje naprawdę jako rzeczywistość cielesna, obecna w wyznaniu wiary, sakramentach i apostolskiej sukcesji". Zob. J. Ratzinger, Eklezjologia Konstytucji Lumen gentium, w: tenże, Kościót. Pielgrzymująca wspólnota wiary, Kraków 2005, s. 131-132.

2 Analizę recepcji soboru i turbulencji, które dotknęły wiele Kościołów lokalnych, teolog podaje w książce: J. Ratzinger, Formalne zasady chrześcijaństwa. Szkice do teologii fundamentalnej, Poznań 2009, s. 491-527. 
Kościoła „z zewnątrz”, ale także na jego życie „wewnętrzne”3. Józef Ratzinger - świadom niebezpieczeństwa rozmycia tożsamości Kościoła, przywołuje i objaśnia kwestie fundamentalne. Pisze i głosi dla ludzi Kościoła. Mniej natomiast wchodzi w polemikę z coraz bardziej zdechrystianizowaną kulturą. Kłopot w tym, że rzecz idzie nie o kwestie praktyczne, zewnętrzne czy tylko strukturalne (w sensie organizacyjne), które w tradycji teologicznej określano jako reformanda (czyli rzeczy, które są w Kościele zmienne), ale o fundamentalne. Mianowicie: jeśli to „my” - czyli aktualnie istniejąca wspólnota ochrzczonych "stanowimy” Kościół, to rzeczywiście możemy go kształtować wedle własnych upodobań. Jeśli jednak jest tak, że utworzył go i nadał mu niezbywalną treść (struktura wiary, sakramenty, apostolskość, prymat) Syn Boży, jest on przede wszystkim Kościołem Chrystusa ${ }^{4}$. Dla Józefa Ratzingera kwestią rozstrzygającą o "dziś" i ,jutro" Kościoła nie są aktualne potrzeby i preferencje jego członków, ale „akty” założycielskie Chrystusa. One definiują, czym Kościół jest, „skąd przyszedł” i po co został ustanowiony ${ }^{5}$.

W tym kontekście bardzo aktualna staje się eklezjologiczna propozycja Józefa Ratzingera. Na przestrzeni wielu lat poprzedzających jego pontyfikat, Benedykt XVI prowadził żmudne badania nad wieloma aspektami natury Kościoła. W imię katolickiej Tradycji podejmował polemikę

${ }^{3} \mathrm{~W}$ tym sensie trzeba zgodzić się z tezą, że z soborem czy bez niego Kościół i tak musiałby zmagać się z destrukcyjnymi tendencjami współczesnej kultury. Zob. M. Jagodziński, Eklezjalne kształty komunii, Radom 2012, s. 49n. Teolog uważa, że przyjęta w XIX i XX wieku strategia tworzenia „kościelnej substruktury”, izolującej katolików od reszty społeczeństwa, już się nie sprawdza. Trzeba „wyjść” z getta i nawiązać dialog z kulturą współczesną. Autor postuluje też uwzględnienie w eklezjologii danych nauk społecznych (przede wszystkim socjologii).

${ }^{4}$ Teolog wskazuje na - najczęściej jest to egzegeza protestancka - źródła niektórych ruchów „odnowy” Kościoła w XX wieku. Egzegeza liberalna już na początku tego stulecia postawiła tezę, że Jezus - będąc kontynuatorem linii prorockiej - definitywnie odrzucił wszelki kult i instytucje religijne. Tym bardziej nie mógł więc - jako przeciwnik instytucji - założyć Kościoła. Nieco później pojawiła się - pod wpływem marksizmu - idea Jezusa „wyzwoliciela”, który - przeciwstawiając się „instytucjom opresji” chce zbudować bezklasowe „królestwo”. Instytucjonalny Kościół (Amtskirche) został dialektycznie przeciwstawiony ludowemu „Volkskirche”. Z drugiej jednak strony szczęśliwie teologia Zachodu przyswoiła sobie (po II wojnie światowej) wypracowaną przez prawosławnych (P. Evdokimov, N. Afanasjew), ideę Ostatniej Wieczerzy, jako aktu założycielskiego Kościoła. Zob. Zur Gemeinschaft gerufen, s. 12n. Por. też Benedykt XVI, J. Ratzinger, Formalne zasady chrześcijaństwa. Szkice do teologii fundamentalnej, Poznań 2009, s. 334 n.

${ }^{5}$ Zob. J. Ratzinger, Zur Gemeinschaft gerufen, s. 9. 
z - nieraz bardzo atrakcyjnie brzmiącymi - nowinkami teologicznymi. Wytrwale bronił tożsamości Kościoła, wykazując, że - przy całej jego „ludzkiej”, historycznie uwarunkowanej ułomności - pozostaje on przede wszystkim dziełem samego Boga, całej Trójcy Świętej.

Nie sposób oczywiście zawrzeć w jednym, krótkim przedłożeniu wszystkich elementów jego bogatej, osadzonej w myśleniu biblijnym i patrystycznym perspektywy. Sednem jego wywodu wydaje się stwierdzenie, że Kościół pielgrzymujący na ziemi jest rzeczywiście sobą, na ile staje się ikoną, re-praesentatio Chrystusa. Zasadne więc będzie przedstawienie tezy „to jest Jego Kościół” w trzech punktach: boska (historiozbawcza) geneza Kościoła; istotne elementy boskiego „wyposażenia” Kościoła; oraz - intrygująca także wielu współczesnych - kwestia świętości Kościoła składającego się z grzeszników.

\section{BOSKA GENEZA KOŚCIOŁA}

Joseph Ratzinger nie ma wątpliwości, że teza głosząca, iż Jezus głosił królestwo Boże, a powstał Kościół, jest z gruntu fałszywa. Posłannictwo Jezusa od początku dokonywało się w kontekście historii zbawienia i Przymierza. Teolog podejmuje - zazwyczaj we współczesnej literaturze eklezjologicznej marginalizowany - problem preegzystencji Kościoła. Jeśli Kościół jest nade wszystko dziełem Boga, problematyka ta - wypracowana jeszcze przez Ojców Kościoła - ma istotne znaczenie ${ }^{6}$. Kardynał Ratzinger za ważny „moment” eklezjotwórczy uważa też fakt Wcielenia Chrystusa ${ }^{7}$.

${ }^{6}$ Por. J. Ratzinger, Braterstwo chrześcijańskie, w: Kościót - znak wśród narodów, s. 33n. Papież o teologicznej genezie Kościoła obszernie traktuje w kontekście przymierza związanego ze stworzeniem. Zob. też Eklezjologia Konstytucji "Lumen gentium", tamże, s. 534n. Por. Cz.S. Bartnik, Kościót, Lublin 2009, s. 89-99. Autor przywołuje patrystyczną doktrynę o „Kościele stworzenia”, „Ecclesia ante legem”, „Ecclesia sub lege” i „Ecclesia sub gratia". Zob. też H. de Lubac, Kościoły Partykularne w Kościele powszechnym, Kraków 2004, s. 171n.

${ }^{7}$ J. Ratzinger wiąże kwestię genezy Kościoła w Tajemnicy Wcielenia z koncepcją Kościoła jako Ciała Chrystusa. Por. Kościót Powszechny sakrament zbawienia w Chrystusie, w: J. Ratzinger, Opera omnia. Kościót - znak wśród narodów. Pisma eklezjologiczne i ekumeniczne, Lublin 2013, s. 213 n. Por. też H. Urs von Balthasar, Antyrzymski resentyment, Poznań 2004, s. 20n. 
Kontekst ustanowienia Dwunastu dowodzi, że w zamiarze Jezusa są oni reprezentacją ludu Izraela i jego przyszłymi sędziami (Mt 19,28; Łk 22,29 n.). Symbolizują więc i urzeczywistniają Izrael czasów ostatecznych, ideę nowego ludu Bożego i definitywnego przymierza Boga z ludzkością̧. Teolog zwraca uwagę, że z symbolem ludu Bożego powiązana jest - co dobitnie widać w Apokalipsie (rozdział 12) - perspektywa kosmiczna. Apokaliptyczna niewiasta oznacza bowiem (obleczona w słońce i księżyc pod jej stopami) rzeczywisty sens kosmosu i całego stworzenia. W rozdziale 20 Oblubienica, ubrana w szaty ślubne na gody Baranka, przedstawia lud Boży w jego ostatecznej, spełnionej formie. Obraz ten dopełnia Miasto i jego 12 bram oraz symbolika raju, ostatecznie odzyskanego 9 Perspektywa Markowa (3,14 n.) jest antycypacją tego, czym naprawdę ma być Kościół: „aby byli z Nim”, by uczestniczyli w Jego misji, której celem jest wyzwolenie od zła "by mieli władzę wypędzać złe duchy". Kościół - lud Boży jest wspólnotą tych, którzy towarzyszą Jezusowi ${ }^{10}$.

Kolejnym „momentem” eklezjotwórczym jest tzw. kryzys galilejski (J 6). Jezus, ekskomunikowany przez synagogę nie przemawia już do tłumów, ale formuje swoich uczniów. Jezus nie wybrał jednak modelu sekty; „nie” oficjalnego Izraela poprowadziło Go do Jerozolimy, gdzie dopełnił swego dzieła zbawczego. Nie jest ono reakcją "przeciw”, ale realizacją idei „hyper pollon” (za wielu) - jak sam podczas Ostatniej Wieczerzy zinterpretował swoją śmierć na krzyżu'i11.

Dla Ratzingera najbardziej wyraźnym i brzemiennym w skutki aktem eklezjotwórczym Chrystusa jest Ostatnia Wieczerza. Jego posiłki (także z wykluczonymi) są objawieniem nieograniczonej dobroci Boga, antycypacją uczty eschatologicznej, zapowiedzią ostatecznej realizacji przymierza. Wszyscy czterej ewangeliści postrzegają Wieczerzę jako „decydującą stację" przed Jego Męką ${ }^{12}$.

Tłem dla słów i gestów Ostatniej Wieczerzy są cztery perykopy Starego Testamentu. W niej bowiem Jezus inkorporował i poddał rein-

${ }^{8}$ Zob. Los Jezusa a Kościót, s. 117 n.

${ }_{9}$ Zob. J. Ratzinger, Los Jezusa a Kościót, s. 119.

10 Zob. tamże, s. 119n.

${ }^{11}$ Zob. tamże, s. 120n. Teolog polemizuje z poglądem, że Jezus zamierzał odłączyć „Resztę" - wspólnotę wybranych. Jego męka i śmierć dowodzą, że nie mogąc już „zdobyć” Izraela przez swoje nauczanie i cuda, „zdobywa” go przez zastępczą śmierć "za wielu”.

${ }^{12}$ Jest ona podsumowaniem wszystkich wcześniejszych uczt Jezusa, stając się kluczowym elementem interpretacji dzieła Jezusa między ludźmi. Zob. tamże, s. 124n. 
terpretacji (objawił ich prawdziwy sens) zasadnicze komponenty Starego Przymierza: wydarzenie Paschy $(\mathrm{Wj} 12)^{13}$, zawarcie przymierza na Synaju (Wj 24), obietnicę nowego przymierza (Jr 31) i Izajaszową ideę sługi Bożego (Iz 53). Zostały one włączone w tajemnicę życia i śmierci Jezusa ${ }^{14}$. W ten sposób mamy do czynienia $\mathrm{z}$ „nową Paschą" i nowym Barankiem paschalnym - Sługą Jahwe, który „umiera za wielu”; mamy zawarcie nowego i definitywnego Przymierza „we krwi Mojej”15, mamy zaczątki nowego ludu Bożego, który mocą ofiary Chrystusa "włącza” starego Izraela i ludy pogańskie.

Istotnym elementem eklezjologii Wielkiego Czwartku jest „nowa świątynia". Nie jest nią już ta w Jerozolimie, ale Ciało Pańskie, czyli Zmartwychwstały Chrystus "w" którym zjednoczeni są wszyscy Jego uczniowie. Jezus bowiem zapowiadał kres starej świątyni i jej odnowienie i udoskonalenie własną mocą ${ }^{16}$.

Genezę Kościoła w specyficzny sposób objaśnia św. Paweł. Mówi o „Ciele Chrystusa”, a o chrześcijanach jako „członkach Chrystusa”. Wy-

13 Ścisły związek Wieczerzy z żydowską Paschą, która była rzeczywistą godziną narodzin ludu Wybranego (nawet wtedy, gdy chronologia pożegnalnego posiłku z uczniami pozostaje nieustalona) dowodzi, że Jezus widzi siebie jako nowego, rzeczywistego - umierającego za całą ludzkość - Baranka paschalnego, a ucztę, w której spożywa się Jego Ciało i Krew czyni definitywną ucztą paschalną. Zob. J. Ratzinger, O genezie $i$ istocie Kościoła, s. 131.

${ }^{14} \mathrm{~J}$. Ratzinger (Los Jezusa, s. 124n.) uważa ten rytualny posiłek za najbardziej oczywistą genezę Kościoła. Nie można - co prawda - mówić o jakiejś prawniczej formule "zakładania" nowej wspólnoty zbawczej. Jednak rekapitulacja starotestamentalnych zapowiedzi (obrazów), jakiej dokonuje Jezus w swojej ofierze krzyża, sprawia, że zostaje ustanowiona istota Kościoła. Jest on bowiem wspólnotą stołu Tego, który - jako Zmartwychwstały - ciągle łamie chleb i gromadzi wokół siebie ludzi wszystkich kultur i czasów. Kościół nie wywodzi się więc z jakichś pojedynczych aktów prawniczych, ale z Osoby Jezusa, z tajemnicy Jego życia i śmierci.

${ }^{15}$ Ostatnia Wieczerza właśnie dlatego, że jest zawarciem Przymierza, jest także konstytucją nowego ludu. Zob. J. Ratzinger, Zur Gemeinschaft gerufen, s. 25n.

${ }^{16}$ Teolog detalicznie pisze o zastąpieniu starego kultu i starej świątyni nowymi, doskonalszymi w książce Das neue Volk Gottes, Dusseldorf 1969, s. 79n. Ewangeliści (Marek, Mateusz, Jan) notują zapowiedzi zburzenia świątyni i zastąpienia jej lepszą „w trzech dniach ją odbuduję". J. Ratzinger dostrzega w nich zapowiedź kresu starego kultu (a wraz z tym zbawczego znaczenia starego ludu) i zastąpienia go nowym porządkiem zbawienia. Wzmianka o rozdarciu zasłony w miejscu najświętszym (Mk 15,38n) w chwili śmierci Jezusa ma więc doniosłe znaczenie teologiczne. Oznacza kres starej świątyni, która utraciła swe "serce”, a w ten sposób prawomocność, by ustąpić miejsca nowej. Jest nią przemienione Ciało Jezusa. Zob. Geneza, istota i misja Kościoła, s. 132. 
raźny jest u niego motyw relacji oblubieńczej (1 Kor 6,12-20); jak w Księdze Rodzaju mężczyzna i kobieta stają się , ,jednym ciałem” w małżeńskiej komunii miłości, tak chrześcijanie są z Chrystusem jednym „Pneuma” czyli nową jednością duchową. W miejsce "starego” Izraela Oblubienicą jest teraz wspólnota wierzących w Chrystusa. Jest ona ludem Bożym dzięki temu, że stanowi Oblubienicę Chrystusa, który czyni z niej swoje duchowe ciało. $Z$ reinterpretacją starotestamentalnej perspektywy Izrael (Oblubienica) - Bóg wiąże się motyw praojca. Chrystus jest praojcem „nowego Izraela”, „nowym Adamem” (Rz 4 i 5; 1 Kor 15; Ga 3). Decydująca jest tu hebrajska koncepcja protoplasty, w którym wszyscy potomkowie stanowią , jedną osobę". Nie jest on jedynie przodkiem, z którego pochodzą kolejne generacje, ale tworzy wraz z nimi „kolektywną” jedność. W nim zawarci są wszyscy potomkowie ${ }^{17}$. Dlatego Paweł używa określenia „,a jak w Adamie wszyscy umierają, tak też w Chrystusie wszyscy będą ożywieni” (1 Kor 15,22). "Przestępstwo jednego” i „czyn sprawiedliwy Jednego" Rz 5,17-18 ${ }^{18}$.

Z semicką ideą „ciała korporacyjnego” czy lepiej „osoby korporacyjnej" wiąże się Pawłowa teologia Kościoła jako "Ciała Chrystusa”. Kościół „sprawiamy” czy „robimy” nie my, lecz Chrystus w nas. Dla Apostoła Narodów istotne są dwa inne konkretne sposoby urzeczywistniania się tej prawdy, czyli idei Kościoła-Ciała Chrystusa. Jest nim Eucharystia: „Chleb, który łamiemy, czyż nie jest udziałem w Ciele Chrystusa ? Ponieważ jeden jest chleb, przeto my liczni, tworzymy jedno ciało" (1 Kor 10,16 n). Skoro sam Pan daje nam swoje ,ja” (to bowiem oznacza dla Semity wyrażenie 'ciało'), a dokładniej „bierze” nas sobie w Komunii - czyli dokonuje zespolenia swojej, zmartwychwstałej, chwalebnej egzystencji z nasza, trudno o mocniejszy argument za jednością tych, którzy w Nim partycypują ${ }^{19}$. Kościół tedy najpełniej „realizuje siebie”, czyli

${ }_{17}$ Zob. Zur Gemeinschaft gerufen, s. 32n.

${ }^{18}$ Potomkowie są wraz ze swym przodkiem ,"jedną osobą", dlatego „w Adamie” są wszyscy ludzie. Dzięki takiemu myśleniu cały lud może nosić imię protoplasty: Jakuba-Izraela. Analogicznie chrześcijanie są ludem Bożym tylko dlatego, że wraz z Chrystusem stanowią jedno, są "Synem w Synu”; że są Ciałem Chrystusa. Dla św. Pawła decydujące jest tu wszczepienie w Chrystusa, drugie narodzenie, które dokonało się przez chrzest (Rz 6,1-11; 1 Kor 12,13a). Ten zaś z kolei wprost „wynika” ze śmierci Chrystusa na krzyżu. Zob. J. Ratzinger, Geneza, istota i misja Kościota, s. 134-135.

${ }_{19}$ Teolog rozwija tę myśl, stwierdzając, że tak jak człowiek, spożywając pokarm, asymiluje go, przyswaja, tak samo Pan asymiluje tych, którzy przyjmują Komunię. Upodabniają się do tego Chleba i w ten sposób stają się między sobą jedno - jednym 
spełnia to, czym jest, poprzez sprawowanie Eucharystii ${ }^{20}$. W niej jednoczymy się z uwielbionym Panem, który tworzy z nas jedno, swoje Ciało. Dla Pawła Kościół jest nie tylko „mistycznym”, lecz także prawdziwym Ciałem Chrystusa. Teologia przez wieki ujmowała to jako Corpus verum Christi; Eucharystię zaś nazywano Corpus mysticum ${ }^{21}$. Przez swoje Ciało sakramentalne (Eucharystię) Chrystus „inkorporuje” przyciąga do siebie chrześcijan, którzy „niosą” w sobie Jego egzystencję. Tak dopełnia się wymowa Wcielenia. W nich Jezus - jak mówią Ojcowie - staje się totus Christus; całym Chrystusem, caput et membra (św. Augustyn) ${ }^{22}$.

Trzecim źródłem Pawłowej idei Ciała Chrystusa jest "filozofia" miłości oblubieńczej. Nawiązuje ona do Księgi Genezis $(2,24)$ „Dlatego to mężczyzna opuszcza ojca swego i matkę swoją i łączy się ze swą żoną tak ściśle, że stają się jednym ciałem". Jedno ciało - to jedna nowa egzystencja. Podobnie dzieje się w Komunii: „Ten zaś, kto łączy się z Panem, jest z Nim jednym duchem" (1 Kor 6,17). Skutkuje więc ona powstaniem jednej, jedynej duchowej egzystencji chrześcijanina z Chrystusem. Teolog wyprowadza stąd wniosek, że dla Pawła Kościół jest Ciałem Chrystusa w taki sposób, w jaki jednym ciałem jest kobieta z mężczyzną. Nie jest "ciałem” w niezróżnicowanej, homogenicznej tożsamości, ale przez pneumatyczno-realny akt miłości oblubieńczej. W tym zespoleniu żaden z podmiotów (czyli Oblubieniec-Chrystus i Kościół-Oblubienica) nie traci

„Jego" Ciałem. Zob. tenże Kościót - powszechny sakrament zbawienia w Chrystusie, s. 215; Zur Gemeinschaft gerufen, s. 26. J. Ratzinger (Zur Gemeinschaft gerufen, s. 33-34) pisze, że Komunia oznacza "przenikanie się” dwóch egzystencji, rodzaj „stopienia” - Verschmelzung - człowieka i Chrystusa. To samo dotyczy wszystkich komunikujących; są oni asymilowani przez ,jeden Chleb" i stają się - w relacji do siebie - ,jednym Ciałem". Jak jednak zauważa w innym miejscu (Geneza $i$ istota Kościoła, s. 216), Pawłowe wyrażenie ,jedno ciało" trzeba rozumieć w „kluczu” oblubieńczym. „Nowa egzystencja” nie oznacza dosłownego „stopienia” się dwóch podmiotów (Chrystus i Kościół), ale „pneumatycznorealny" akt oblubieńczej miłości. Kościół nie staje się Chrystusem (i odwrotnie), ale pozostaje - w dynamicznej relacji dojrzewania - służebnicą, którą Pan udoskonala i wynosi do godności swej oblubienicy.

${ }^{20}$ Ratzinger - rozważając pojęcie chrześcijańskiego braterstwa - precyzuje, że wspólnota lokalna Kościoła realizuje się w zgromadzeniu kultowym czyli przede wszystkim na Eucharystii. Fundamentem braterskich relacji wszystkich członków Kościoła nie są "relacje poziome” czy społeczne, ale zjednoczenie wszystkich w jednym Ciele Pana czyli concorporatio cum Christo. Zob. tenże, Braterstwo chrześcijańskie, s. 74.

${ }^{21}$ Zob. Geneza, istota i misja Kościota, s. 136.

${ }^{22}$ Zob. J. Ratzinger, O genezie $i$ istocie Kościota, s. 137n.; tenże, Kościót i liturgia, s. 152 . 
swej tożsamości ${ }^{23}$. Kościół nie staje się Chrystusem, lecz pozostaje - w dynamicznej relacji - „służebnicą”, którą Pan, miłując, czyni stopniowo swą Oblubienica, ta zaś nie przestaje szukać Jego oblicza. Dlatego ze strony Kościoła zawsze istnieje możliwość niewierności i nieustanna konieczność odnowy i nawrócenia ${ }^{24}$.

Dla Pawłowej eklezjologii istotne znaczenie ma terminologia, zwłaszcza określenie eklesia, eklesia tou Theou. J. Ratziger podkreśla, że w odróżnieniu od znaczenia tego terminu w świecie greckim, jak i w judaizmie synagogalnym - chrześcijańskie „zwołanie” ma chrystocentryczny „środek”, skonkretyzowany w Uczcie Pana ${ }^{25}$.

Józef Ratzinger za integralną i konieczną uważa Łukaszową perspektywę eklezjologiczną, zawartą w Dziejach Apostolskich. Określa je jako „eklezjologię narracyjną". W największym skrócie ma ona trzy odsłony:

- pierwsza dokonuje się w wieczerniku, gdzie zgromadzeni byli apostołowie, grupa innych uczniów z Maryją na czele. Jedenastu (imienna lista), Maryja, niewiasty i bracia to autentyczny qahal, zgromadzenie ludu przymierza w zalążku, zgromadzone jednomyślnie na modlitwie, która wyraża ich jedność. Nawet wybór Macieja (na miejsce Judasza) ukazuje działanie wspólnoty jako przygotowanie; wybór zostaje zarezerwowany Bogu ${ }^{26}$;

- obraz drugi (Dz 2) definiuje nowonarodzony Kościół przy pomocy czterech określeń: trwanie w nauce apostołów (zaczątki sukcesji apostolskiej i urząd świadka następców apostołów); trwanie we wspólnocie, na łamaniu chleba i modlitwach. Widać tu wyraźnie, że Słowo i Sakrament już wtedy są filarami żywej budowli Kościoła. Posługa Słowa powiązana jest z instytucją i osobistą odpowiedzialnością świadka;

- pośrodku tych dwóch obrazów znajdujemy wydarzenie Pięćdziesiątnicy. Gwałtowny wicher i ogień Ducha Świętego ustanawiają Kościół. Jest jasne, że Kościół nie jest efektem zabiegów i starań ludzkich; on jest stworzeniem Ducha Świętego. Dlatego dar Du-

${ }^{23}$ Zur Gemeinschaft gerufen, s. 35. Autor dodaje, że wyrażenie ,jednym duchem" oznacza u Pawła jedną duchową egzystencję z Tym, który w zmartwychwstaniu jest „Duchem” z „Ducha” i stał się „Ciałem” w Jego wylaniu.

${ }^{24}$ Zob. tamże, s. 215-217.

${ }^{25}$ Zob. J. Ratzinger, Zur Gemeinschaft gerufen, s. 27 n.

${ }^{26}$ Zob. J. Ratzinger, Kościót - powszechny sakrament zbawienia w Chrystusie, s. 218. 
cha jest odwróceniem, antytezą, przezwyciężeniem babilońskiego ducha tego świata. Ten bowiem motywowany "wolą władzy" - która chce panować i ujarzmiać - zmierza do ujednolicenia. Rodzi zaś nienawiść i podziały. Duch Boga jest miłością; dlatego przyjmuje różnorodność i przemienia ją w jedność. Ludzie różnych języków rozumieją się wzajemnie ${ }^{27}$.

Dla J. Ratzingera obraz Pięćdziesiątnicy ma doniosłe skutki eklezjologiczne. Po pierwsze: przenikanie się w Kościele „z Ducha” wielości i jedności - w Kościele jest wielość kultur, języków, a jednocześnie dar jedności. Już widać zarys Kościoła, który jest jeden właśnie przez to, że żyje "subsistit” w licznych, zróżnicowanych Kościołach partykularnych ${ }^{28}$. Po wtóre: już w chwili swych narodzin Kościół był powszechny, był Kościołem całego świata, Ecclesia universalis, mówiąca wszystkimi językami. On z kolei rodzi Kościół w wielu innych miejscach, które - za każdym razem - są urzeczywistnieniem, konkretyzacją, "lokalizacją" jednego, jedynego Kościoła. Chronologiczne i ontologiczne pierwszeństwo Kościoła powszechnego sprawia, że jest on w ogóle Kościołem ${ }^{29}$.

Przywołane wyżej elementy bogatej teologii Kościoła Józefa Ratzingera podkreślają jego objawiony, boski początek, zakorzeniony w historiozbawczej inicjatywie Trójcy Świętej, zrealizowanej w osobie i dziele Chrystusa i permanentnym działaniem Ducha Świętego.

\section{TREŚCIOWE STRUKTURY KOŚCIOŁA JAKO RE-PRAESENTATIO CHRISTI}

Wywód profesora Ratzingera nie koncentruje się na "osobnym” traktacie o hierarchii, ustanowieniu Dwunastu, prymacie Piotra ${ }^{30}$. Choć w jego eklezjologii wyposażenie Kościoła przez Zbawiciela w konkretną strukturę znajduje należne miejsce, najciekawsze wydaje się oparcie tajemnicy Eklezji na Eucharystii. Dla niego wszystko wynika z „centrum”,

27 Zob. tamże, s. 218-219.

${ }^{28}$ Zob. J. Ratzinger, Powwszechność i katolickość, s. 180n.

${ }^{29}$ Zob. Kościót - powszechny sakrament zbawienia w Chrystusie, s. 217n.; Kościót i liturgia, s. 147n.

${ }^{30}$ Kwestię prymatu Piotra i sukcesji po nim podejmują teksty: Prymat (s. 558-561), Prymat Piotra a jedność Kościoła (s. 562-578), Prymat a episkopat (s. 579-606), Prymat papieża a jedność ludu Bożego (s. 607-621). Zob. też. J. Ratzinger, Zur Gemeinschaft gerufen, s. 44n. 
którym jest celebrowanie Ciała Chrystusa. Ta właśnie Tajemnica jest „kluczem” do właściwego rozumienia urzędu apostolskiego, posługi prymacjalnej, sukcesji apostolskiej. Z przemyślanej Eucharystii wynika prawdziwa „kościelna”, chrześcijańska miłość (cudowne słowa św. Jana Chryzostoma) $)^{31}$; z niej wynika też eklezjalny porządek. Kościół, który rozumie Eucharystię jako podstawę bycia Ciałem Chrystusa, jest nie tylko wspólnotą miłujących się ludzi, lecz także Kościołem świętego porządku. W celebracji eucharystycznej jest praźródło idei prymatu. Dlatego Paweł z naciskiem żąda od Koryntian zachowania ustalonego porządku. Kościół starożytny widział siebie jako wspólnotę Ostatniej Wieczerzy. Każda lokalna wspólnota postrzegała siebie jako widzialną postać (partykularne urzeczywistnienie, Ortskirche) jednego, powszechnego Kościoła Bożego, który pod przewodnictwem biskupa i jego prezbiterium celebruje tajemnicę Ciała Chrystusowego. Jedność między wspólnotami nie miała charakteru administracyjnego, lecz „komunijny”: na zasadzie wzajemności dopuszczano do Stołu Pana członków innych wspólnot. Z heretykami nie. Jak rozpoznać jednych od drugich? Działała zasada biskupia: gdy ktoś wybierał się do innej odległej miejscowości, brał od swego biskupa list komunijny, potwierdzający przynależność do Wielkiego Kościoła. Biskupi mieli spisy ortodoksyjnych wspólnot lokalnych. Po drugie: kto komunikuje z Rzymem, ten jest w komunii z prawdziwym Kościołem; z kim Rzym nie komunikuje, ten do rzeczywistej komunii nie należy. Biskup Rzymu konkretyzuje, uosabia jedność, którą Kościół czerpie z Eucharystii. Jedność Kościoła nie pochodzi więc najpierw z jednej centralnej władzy; ona wyrasta z tego, że Wielki, prawdziwy Kościół żyje jedną Eucharystią ${ }^{32}$. Biskup Rzymu tę jedność konkretyzuje, ją utrzymuje w czystości. Kto się z nim nie zgadza, odłącza się od pełnej communio jednego, niepodzielnego Kościoła. „Teologicznym miejscem” prymatu jest tedy Eucharystia, w niej urząd i duch, prawo i miłość mają swe cen-

31 "Czym jest ten chleb? Ciałem Chrystusa. Czym stajemy się my, którzy go otrzymujemy? Nie wieloma ciałami, lecz jednym Ciałem. Jeśli więc wszyscy tym samym żyjemy i wszyscy tym samym się stajemy, dlaczego nie okazujemy sobie tej samej miłości, dlaczego nie stajemy się jedno także w tym znaczeniu?". In 1 Cor. Hom. 24 (200).

32 Dana Kościołowi obiektywno-reprezentacyjna misja-kontynuacja wstawiennictwa Chrystusa postuluje jedyność Kościoła. Jeśli sens istnienia Kościoła stanowi repraesentatio, publiczne ukazywanie Bożej rzeczywistości zbawienia (czyli bycie 'sakramentem'), to logicznie może być tylko jeden taki znak. Zob. J. Ratzinger, Braterstwo chrześcijańskie, s. 87n. Por. też: Zur Gemeinschaft gerufen, s. 26. 
trum i punkt wyjścia ${ }^{33}$. Koresponduje z tym piękne zdanie św. Ignacego Antiocheńskiego w Liście do Smyrnian: Gdzie pojawi się biskup, tam niech będzie wspólnota; tak, jak gdzie jest Chrystus Jezus, tam i katolicki Kościół $(8,2)$. Gdzie jest biskup, tam jest Kościół, „Biskupem” zaś całego Kościoła jest Jezus Chrystus ${ }^{34}$.

Kościół jest jakby 'namiotem Logosu', stałą obecnością Słowa Bożego w świecie. Wpierw było posłannictwo apostolskie, i zwiastowanie Chrystusa (kerygma), która domaga się upoważnienia, władzy. Tam, gdzie jest słowo, tam jest świadectwo, a wiarygodne świadectwo zakłada władzę $e^{35}$. Diadoche to (Tradycja-przekazywanie i sukcesja) święta posługa, a zarazem władza Chrystusa, której „narzędziami” są biskupi z papieżem na czele. Struktura ta ma charakter pneumatyczny i chrystologiczny, a dopiero wtórnie organizacyjny. Uznanie Kanonu Pisma i Credo przez Kościół w Rzymie wskazuje zarówno na organiczną jedność treści wiary i żywej struktury Kościoła, jak i na nieustannie ożywianą przez Ducha Świętego Tradycję, zapodmiotowaną w sukcesji apostolskiej ${ }^{36}$.

Nikt nie może sam siebie uczynić Kościołem. Kościół Chrystusa "staje się obecny" przez przedstawiciela coetus-collegium episcoporum. Kościół jest więc zawsze „darem” Zmartwychwstałego, a nie dziełem oddolnej inicjatywy. J. Ratzinger - przywołując naukę Vaticanum II - polemizuje tu z protestantyzmem, który faktycznie rezygnuje z klasycznego pojęcia Kościoła, zastępując je terminem „wspólnota”37. Wykazuje też braki prawosławnej eklezjologii eucharystycznej, twierdzącej, że każda wspólnota eucharystyczna jest już w pełni Kościołem ${ }^{38}$.

${ }^{33}$ J. Ratzinger wiąże prymat - tak samo jak urząd biskupi - z eklezjologią eucharystyczną.

${ }^{34}$ Zob. J. Ratzinger, Eklezjologia II Soboru Watykańskiego, s. 239n.

${ }^{35} \mathrm{O}$ ontologicznym utożsamieniu przepowiadającego kapłana z Chrystusem, które pozwala na określenie, że działa on „in persona Christi Capitis” i „in persona Ecclesiae" zob. J. Ratzinger, Posługa i życie kapłanów, w: Kościót. Pielgrzymująca wspólnota wiary, Kraków 2002, s. 139-158.

${ }^{36}$ J. Ratzinger prezentuje obszernie tę kwestię w: Prymat Piotra a jedność Kościota, s. $562-606$.

${ }^{37}$ Nie dostrzegając w Kościele rzymskim Ducha Chrystusa, Luter nie nazywał „Kościołami” także protestanckich Kościołów krajowych, powstałych z reformacji.

${ }^{38}$ Zob. J. Ratzinger, Eklezjologia II Soboru Watykańskiego, s. 240n. 


\section{3. ŚWIĘTY KOŚClÓł GRZESZNIKÓW / SKANDAL CHRZEŚCIJAŃSTWA}

Ratzinger nie wychodzi od klasyki, czyli długiej tradycji usiłującej rozwiązać dylemat: w jaki sposób „pogodzić” grzeszność wszystkich członków Kościoła pielgrzymującego z wiarą w jego świętość39. Nie dezawuując bynajmniej argumentacji „ze znamion” (nota Ecclesiae), czyli definicji świętości, struktury sakramentalnej, świętej władzy, świętości doskonałości wybranych ludzi Kościoła, proponuje wizję dynamiczną. Ponieważ punktem wyjścia jest zbawcze dzieło Chrystusa, uwzględnia ona (a wręcz zakłada) grzeszność wszystkich Jego uczniów ${ }^{40}$. Ponieważ Kościół (pielgrzymujący, cierpiący i tryumfujący) jest wspólnotą osób, świętość oznacza pełną realizację godności osoby w relacji do świętej wspólnoty Trójcy. Dlatego w pojęciu „świętości” Kościoła trzeba bardziej akcentować dynamiczną partycypację wierzących w miłości Trzech Osób, niż "obiektywną" prawdę oddzielającą sacrum od profanum ${ }^{41}$. Z drugiej strony Józef Ratzinger akcentuje „nadobfitość", nadmiar Bożej łaski, która - zawsze "przekraczając" naturalne uzdolnienia i kwalifikacje ludzi, działa „mimo” człowieczej słabości. „Kościół nie jest ideą, lecz Ciałem, a zgorszenie Wcielenia, na którym potknęło się wielu współczesnych Jezusowi, trwa dalej w zgorszeniach Kościoła. Jednak i tutaj prawdą są słowa: Błogosławiony, kto się Mną nie zgorszy" - stwierdza Józef Ratzinger, mówiąc o historycznym uwarunkowaniu „Chrystusa w nas”. Zanurzenie

${ }^{39}$ S. Nagy wyodrębnia świętość obiektywno-ontologiczną i subiektywno-dynamiczną czyli moralną. Ta pierwsza oznacza obecność Boga (posłannictwo trynitarne Chrystusa i Ducha Świętego) w Kościele: depozyt wiary, sakramenty i święte posługi. Druga to świętość członków Kościoła, złączona z permanentną koniecznością nawrócenia i przemiany. Konstytucja Lumen gentium (nr 39) jednoznacznie potwierdza (jest on uznawany przez wiarę za "nieskazitelnie święty") tradycyjną doktrynę o świętości Kościoła. Por. S. Nagy, Chrystus w Kościele, Wrocław 1982, s. 169n.

${ }^{40}$ Teolog (analizując koncepcję ciała Chrystusa) stwierdza, że Kościół nie utożsamia się z Chrystusem, ale jako „Kościół grzeszników” nieustannie potrzebuje oczyszczenia i odnowy, by „stawać się Kościołem”. Zob. Kościót - powszechny sakrament zbawienia w Chrystusie, s. 247. Autor za Ursem von Baltasarem stwierdza, że grzesznicy, aczkolwiek są w Kościele „u siebie” - jednak na ile są grzeszni, nie wyrażają w sobie pełni „zadanej” im świętości. Na etapie ziemskiego pielgrzymowania oblubienica Chrystusa okazuje się pomarszczona, pełna skaz i grzeszników. Zob. tamże, s. 314-315.

${ }^{41}$ Personalistyczny sens „świętości” podkreśla Cz.S. Bartnik. W rozumieniu chrześcijańskim pojęcie świętości jest bliskie miłości, a osoby ludzkie partycypują w Osobach-Świętościach. Inaczej mówiąc, świętość jest najwyższym darem Kościoła, a polega na obecności Boga w ludziach. Zob. Kościót, Lublin 2009, s. 257-259. 
wspólnoty Kościoła w świat, kulturę, konkretne realia polityczne, oznacza nieusuwalne napięcie między grzechem a łaską ${ }^{42}$

Ratzinger, by unaocznić radykalną „nowość" Ewangelii, przywołuje soteriologię św. Pawła, zawartą w Liście do Rzymian. Apostoł przeciwstawia Stare Przymierze Nowemu; tamto (np. Pwt 11,22-31; 28) jest warunkowe. Bóg mówi: jeśli wypełnicie Prawo, uczynicie wszystko, co jest napisane u Mojżesza, będziecie ocaleni. Jahwe chce zbawić Izraela, o ile - jeżeli - Izrael wypełni Prawo! Przymierze, jego skuteczność, jest związane z ludzką moralnością, wypełnieniem „wszystkich przepisów Prawa”. To jest jednak niemożliwe, albowiem żaden człowiek nie jest całkowicie dobry. Taka była też rola proroków: przypominać, że cała wspaniałość kultu nie pomoże, jeśli nie zostanie wypełnione całe Prawo $^{43}$. Dlatego Stary Testament nie gwarantował pełni Bożych darów; był zbawczo nieskuteczny i niepełny.

Nowy Testament oznacza, że Bóg sam staje się człowiekiem, że w człowieku Jezusie Chrystusie Bóg przyjmuje ludzkość. Bóg zawiera nowe, bezwarunkowe przymierze, nowy lud Boży został przyjęty przez Boga nie „pod warunkiem”, ale absolutnie: jego przyjęcie i nieodwołalność nie opierają się na chwiejnym conditionalis ludzkiej moralności, ale na absolutum zbawczego czynu Jezusa Chrystusa. Kościół - inaczej niż Izrael - opiera się nie na „poczciwości” czy prawości ludzi, ale na łasce okazanej „mimo” całej niemoralności ludzi, czyli na Wcieleniu Bożego Syna $^{44}$. Dlatego Kościół nie jest „warunkowy”, ale absolutny, oparty na absolutności Boga. Z powodu takiej „postawy” Boga Kościół nigdy nie może być odrzucony; jest zawsze i wszędzie 'świętym' Kościołem - ze względu na nienaruszalne „mimo to” łaski Bożej. Dlatego Kościół jest

${ }^{42}$ Zob. Eklezjologia II Soboru Watykańskiego, s. 238.

${ }^{43}$ Zob. Otwartość i postuszeństwo. Stosunek chrześcijanina do swojego Kościoła, s. 415.

${ }^{44}$ Uznając Wcielenie za uzasadnienie instytucjonalnego elementu Kościoła Ratzinger dodaje, że tajemnica Chrystusa jest tajemnicą Krzyża. Wcielenie ku niej prowadzi. Dlatego Kościół, będący w pewnym sensie kontynuacją Wcielenia, musi nieustannie „przechodzić” przez tajemnicę Krzyża, oczyszczenia i dojrzewania. W „czasie historycznym" święty Kościół zawsze pozostaje Kościołem grzesznym, który błaga Boga o odpuszczenie. Zob. Otwartość i postuszeństwo, s. 417. W innym tekście (Krytyka Kościoła?, s. 447n.) Teolog wspomina o nadużywaniu zasady inkarnacyjnej, prowadzące do fałszywej diwinizacji niektórych eklezjalnych instytucji i rozwiązań organizacyjnych. Iunctim misterium Incarnationis et crucis musi oznaczać "tymczasowość" wszystkich ziemskich instytucji w Kościele. 
absolutny, święty, w swym najgłębszym rdzeniu niezniszczalny ${ }^{45}$ • „Kościół jest definitywnym, nieprzekraczalnym miejscem zbawczego działania Bożego względem człowieka" - stwierdza Autor ${ }^{46}$. Według Ratzingera „Credo Ecclesiam" oznacza: wierzę w to, że Bóg przez ten Kościół dokonuje w świecie zbawienia. Z drugiej strony: ponieważ Kościół jest z łaski, do jego istoty należy także to, że ludzie, którzy go tworzą, są grzesznikami. Pozostaje casta meretrix, który Chrystus obmył krwią i uczynił z niej oblubienicę. H. Urs von Balthasar dodaje, że dlatego właśnie chrześcijanie przeżywają stałe napięcie egzystencjalne (Kościół uczestniczy permanentnie w „kryzysie Krzyża”). Kościół wszechczasów żyje mocą przebaczenia, które z nierządnicy czyni oblubienicę. Jest zawsze Kościołem „z łaski”47. Kwestia świętości Kościoła i jego grzeszności „w członkach” szczególnie ostro wybrzmiała w jubileuszu 2000. Komentując wyznanie grzechów, jakiego dokonał Jan Paweł II oraz dokument Międzynarodowej Komisji Teologicznej „Pamięć i pojednanie. Kościół i winy przeszłości” Józef Ratzinger pyta, komu należy przypisać winę (odpowiedzialność) za grzechy historii Kościoła? Liturgia podkreśla bowiem jednostkową, osobistą odpowiedzialność: „Ja zgrzeszyłem”. Ale jednocześnie każde ,ja” jest włączone we wspólnotę Kościoła, który błaga Boga o przebaczenie ${ }^{48}$. Jednostronne potępienie Kościoła przez protestantyzm i oświecenie wywołało postawę apologetyczną i spowodowało „osłabienie” w katolicyzmie siły wyznawania grzechów. Okropności dokonane w XX wieku przez systemy odwołujące się do ateizmu umożliwiają Kościołowi z otwartością wyznawać grzechy; trzeba wszakże zachować pewne zasady. Kościół współczesny nie może z siebie czynić trybunału, osądzającego wcześniejsze pokolenia. Wyznawać grzechy znaczy (za św. Augustynem) „czynić prawdę”; nie

${ }^{45}$ Zob. tamże, s. 415n. Ratzinger zauważa, że radykalna, prowadzona $\mathrm{w}$ duchu profetycznym krytyka Kościoła jest - właśnie z powodu gwarantowanej przez samego Boga jego świętości - nieaktualna, wręcz niemożliwa. W innym wykładzie (Krytyka Kościota?, s. 446) Teolog precyzuje, że „nowy profetyzm” czyli krytyka Kościoła musi przeistoczyć się w charyzmat, dar Ducha dla Kościoła. Co oznacza, że krytykuje się „ludzi w Kościele”, a nie sam Kościół.

46 Zob. tamże, s. 416.

47 Por. H. Urs von Balthasar, Antyrzymski resentyment, Poznań 2004, s. 183n.

${ }^{48}$ Zob. Wina Kościota, s. 455 n. Ratzinger przywołuje tu „Confiteor”, chrześcijański zwyczaj odmawiania psalmów pokutnych oraz profetyczne napomnienia Apokalipsy do siedmiu Kościołów. Począwszy od reformacji rozpoczyna się totalna krytyka Kościoła, czyniąca zeń uosobienie największego zła w dziejach ludzkości. W konsekwencji kulturowej stygmatyzacji także niektórzy katolicy przestali wierzyć w świętość Kościoła. 
należy tedy ani negować zła popełnianego niegdyś w Kościele, ale tym bardziej nie wolno przypisywać Eklezji grzechów „na wyrost”. W końcu trzeba pamiętać, że chrześcijańska confessio peccati musi iść w parze z confessio laudis. Bóg jest w swym miłosierdziu zawsze większy niż słabość Jego dzieci. Łatwo - zwłaszcza w klimacie mody na krytykę Kościoła ulec złudzeniu "przewagi" $\mathrm{zła}^{49}$.

Benedykt XVI aplikuje te wnioski szczególnie do papiestwa, a wcześniej do prymatu Szymona Piotra. Albowiem jego zdaniem, Boży paradoks, objawiający boskość Kościoła w kruchym, grzesznym, ułomnym „naczyniu” czyli człowieku, jest najbardziej ewidentny w historii papiestwa. Nadanie prymatu u Jana (21,15-17) dokonuje się w tle zaparcia się Piotra. U Mateusza (16,17n.) - opoka zostaje nazwana Szatanem, kamieniem zgorszenia, zawadą: jeśli rzecz idzie tylko o naturę ludzką Szymona, można go nazwać szatanem i kamieniem obrazy; jeśli zaś w grę wchodzi „dar” Boga - może stać się kosmiczną opoką. Nie jest to wynikiem jego własnych wysiłków, kwalifikacji intelektualno-moralnych, własnego charakteru, lecz nomen officii. Siła i niezawodność „skały” ma związek z "udzieloną" służbą, z wybraniem od Boga i zadaniem, do realizacji którego nikogo nie uzdalnia własny charakter. Ratzinger akcentuje paradoks Bożej mocy, który działa w słabości. Teolog stwierdza: „Napięcie pomiędzy darem od Pana a własnymi możliwościami rzuca się tu od razu w oczy. Jest to niejako antycypacja całego dramatu dziejów papiestwa, w którym ciągle powtarza się jedno i drugie: papiestwo pozostaje fundamentem Kościoła nie dzięki swej własnej mocy, a jednocześnie poszczególni papieże - jeśli polegają tylko na swych ludzkich możliwościach - ciągle na nowo stają się zgorszeniem, ponieważ chcą wyprzedzać Chrystusa, nie zaś Go naśladować"50. Także u Łukasza (22,32n.) obietnica pierwszeństwa i skutecznego opierania się Kościoła atakom zła wiąże się z zapowiedzią zaparcia się. Wniosek: obietnicy Bożej mocy zawsze towarzyszy ludzka słabość, dlatego Zbawcą - w każdej sytuacji -pozostaje nie człowiek, lecz Bóg. Ciągle ewidentne jest owo „mimo to” Bożej łaski, która nie traci nic ze swej mocy z powodu niezdolności człowieka ${ }^{51}$.

49 Zob. J. Ratzinger, Wina Kościoła, s. 458-460.

${ }^{50}$ Zob. Prymat Piotra a jedność Kościoła, s. 570.

${ }^{51}$ Warto przywołać niezwykle sugestywne słowa J. Ratzingera: „Niedorastanie człowieka do tej funkcji (czyli posługi Piotrowej - dop. J.P.) jest tak krzykliwe i rażące, że właśnie w powierzeniu człowiekowi funkcji Opoki widać, że Kościół podtrzymują nie ci ludzie, lecz On sam, dokonując tego bardziej mimo ludzi niż przez nich. Tajem- 
W tym kontekście nie ma sensu - zdaniem J. Ratzingera - rozróżniać przed (słaby, grzeszny) i po paschalnego - rzekomo idealnego - Piotra ${ }^{52}$. Nie można więc odłączać „Kościoła” i „ludzi w Kościele”. Abstrakcyjna wolność Kościoła od wszelkiej zmazy nie ma realnego, historycznego sensu. Kościół żyje w ludziach tego doczesnego świata, żyje mimo Boskiej tajemnicy, którą zawiera w sobie, na autentycznie ludzki sposób. Jako instytucja dźwiga ciężar człowieczeństwa; mimo to i właśnie dlatego, święty i grzeszny Kościół jest świadectwem i rzeczywistością zawsze niepokonalnej łaski Boga, Jego coraz większej łaskawości, która nas kocha z całą naszą niegodziwością. Stwierdziwszy to kardynał Ratzinger pyta, jak w takim razie powinno wyglądać świadectwo chrześcijanina. Nie może się on zgodzić (po prostu przyjąć do wiadomości) zła i grzechu, jakiego dopuszczają się dzieci Kościoła. Kochając Kościół powinien spełniać posługę profetyczną; jej elementem musi być posłuszeństwo, a z nim gotowość na cierpienie (męczeństwo). Przykładem takiej profetycznej postawy: sprzeciwu wobec zła, ale także zdolności do cierpienia „w” Kościele i „dla” Kościoła było wielu świętych ${ }^{53}$. Prawda ta znajduje odzwierciedlenie w przeświadczeniu, że udzielona Szymonowi przez Chrystusa „władza kluczy” nie polega jedynie na decyzjach doktrynalnych czy zwierzchności administracyjnej. Jej istotą (związywanie i rozwiązywanie) jest odpuszczanie grzechów. Misją Piotra jest łaska przebaczania. Ona jest dla Kościoła konstytutywna, podstawowa, bo Kościół jest społecznością grzeszników, którzy potrzebują zbawienia ${ }^{54}$.

nica Krzyża nie jest prawdopodobnie nigdzie tak widoczna jak w kościelno-historycznej rzeczywistości prymatu. To, ze jego centrum stanowi przebaczenie, jest jednocześnie jego wewnętrznym warunkiem i znakiem szczególnej mocy Bożej". Zob. Prymat Piotra a jedność Kościoła, s. 577.

${ }^{52}$ Teolog uważa za niewłaściwe i niezgodne z prawdą idealizowanie Piotra po wydarzeniu Pięćdziesiątnicy. Przedpaschalny i popaschalny Piotr jest ciągle tym samym człowiekiem. Odważnie wyznaje wiarę, a jednocześnie nie jest wolny od słabości. Ratzinger przywołuje spór Pawła z Piotrem w Antiochii (Ga 2,11n.). Zob. Otwartość i postuszeństwo, s. 420.

${ }^{53}$ Ratzinger jako przykład owocnego sentire ecclesiam przywołuje m.in. Franciszka z Asyżu i Ignacego Loyolę. Zob. Otwartość i posłuszeństwo s. 422n.

${ }^{54}$ Autor dodaje, że kluczem do królestwa niebieskiego są słowa przebaczenia, których nikt z ludzi nie może powiedzieć sam z siebie. Ich niezawodność gwarantuje jedynie sam Bóg. Dlatego zapowiedź prymatu (Mt 16, 17-19) wiąże się z zapowiedzią Jezusowej Męki. Zob. J. Ratzinger, Prymat Piotra a jedność Kościoła, s. 571n. Por. H. Seweryniak, Święty Kościót powszedni, Warszawa 1996, s. 84. 
W Kościele istnieje ciągle paradoks, napięcie winy i łaski, które Ojcowie wyrażali cytatem „Nigra sum sed formosa” (Pnp 1,5). „Jestem splamiona grzechami, lecz piękna". Słowa te pokazują, że Kościół może odważnie i ufnie wyznawać grzechy doby obecnej i przeszłości, ponieważ wie, że Pan jest silniejszy od zła. On swój Kościół nieustannie odnawia i ubogaca dobrem, On jest gwarantem jego wzrostu i trwania.

\section{ZAKOŃCZENIE}

Dla Józefa Ratzingera Kościół jest rzeczywistością teologiczną. Posiada on - owszem - konieczny wymiar ludzki, instytucjonalny, historyczny. Ale jest on przede wszystkim Chrystusowy. Dlatego „miarą" życia eklezjalnej wspólnoty nie mogą być, choćby solidnie uzasadnione, potrzeby chwili, mody kulturalne czy ideologiczne. Kościół, choć zanurzony w historii, nie może zachować swej tożsamości, odwołując się do oczekiwań czy aspiracji pokolenia, które w danej chwili go (in statu peregrinationis) stanowi. Rozstrzygające są bowiem „miarodajne początki" czyli geneza; kościelnotwórcze działanie Chrystusa i życie Kościoła apostolskiego. Wśród elementów boskiej genezy Kościoła, która stanowi o jego naturze i posłannictwie, Teolog akcentuje przede wszystkim wydarzenie Pięćdziesiątnicy i Ostatniej Wieczerzy. Konsekwentnie tedy najwyższą formą urzeczywistniania się Chrystusowej wspólnoty i komunii ze Zbawicielem jest Eucharystia. W niej Kościół staje się najdosłowniej repraesentatio Christi. Z drugiej zaś strony właśnie Eucharystia, która buduje i sprawia z ludzi Ciało Chrystusa, domaga się posługi Piotrowej i jednego episkopatu. Ona też unaocznia kwintesencję istoty Kościoła i jego misji: odkupienie czyli wyzwolenie z mocy grzechu. Jak chyba żaden ze współczesnych teologów Benedykt XVI z predylekcją podkreśla paradoks Bożej miłości i mocy, która objawia się i manifestuje w Kościele złożonym z samych grzeszników. Warunkiem urzeczywistnienia się Bożej łaski jest uznanie i wyznanie grzechów, prowadzące do wielbienia Boga bogatego w miłosierdzie.

Streszczenie. Dla Józefa Ratzingera Kościół jest rzeczywistością teologiczną. Posiada on konieczny wymiar ludzki, instytucjonalny, historyczny. Ale jest on przede wszystkim Chrystusowy. Kościół, choć zanurzony w historii, nie może zachować swej tożsamości odwołując się do oczekiwań czy aspiracji pokolenia, które w danej chwili go (in statu peregrinationis) stanowi. Wśród elementów boskiej 
genezy Kościoła, wymienić należy przede wszystkim wydarzenie Pięćdziesiątnicy i Ostatniej Wieczerzy. Konsekwentnie tedy najwyższą formą urzeczywistniania się Chrystusowej wspólnoty i komunii ze Zbawicielem jest Eucharystia. W niej Kościół staje się najdosłowniej repraesentatio Christi.

Słowa kluczowe: Kościół; eklezjologia; Józef Ratzinger.

Abstract. "This is his Church". Divine dimension of Joseph Ratzinger ecclesiology. According to Joseph Ratzinger, the Church is a theological reality. We can see that she is characterized by a three essential earthly realties: the human, the institutional and the historical. But it would be impossible to understand her without seeing primarily that her identity is rooted in her belonging and being joined to Christ. The Church, though inserted in history, cannot preserve her identity by merely appealing to the expectations and aspirations of people who situate her at a certain moment in time (in statu peregrinationis). Taking seriously those divine elements of the Church's beginning lead us to an essential self understanding of her identity as bound by what happens at Pentecost, and the Last Supper. Consequently to fully understand the union of Christ's community with the Saviour, a full understanding of the dynamic life of the Eucharist must be expolored. It is in and through the Eucharist where the Church becomes in the strictest sense, repraesentatio Christi.

Keywords: Church; ecclesiology; Joseph Ratzinger. 
